\title{
Using Powerpoint Media to Learning Outcomes Theme 4 Sub-theme 2 Learning 6 in Class III Students of SD Negeri 1 Karanganyar Academic Year 2020/2021
}

\author{
Yuliana Yustina Pancawati \\ SD Negeri 1 Karanganyar \\ yyustinap@gmail.com
}

\section{Article History}

accepted $14 / 11 / 2020$

published $26 / 11 / 2020$

\begin{abstract}
The purpose of this research was to improve learning outcomes in theme 4 sub-theme 2 learning 6 grade III elementary schools with a powerpoint media. The research conducted was a Classroom Action Research (PTK) with three cycles, with each cycle consisting of two meetings. The stages of each cycle are planning, implementing, observing and reflecting. Each meeting is carried out a pre test and post test to determine the progress of students. In the first cycle the students who completed after carrying out the post test were 35\%. In the second cycle students who completed after carrying out the post test were $60 \%$. In the third cycle students who completed after carrying out the post test were $90 \%$. These results indicate that powerpoint media can improve student interest and learning outcomes, especially grade III theme 4 subtheme 2 learning 6 at SDN 1 Karanganyar.
\end{abstract}

Keywords: Student interest, learning outcomes, powerpoint media

\begin{abstract}
Abstrak
Tujuan dari penelitian ini adalah untuk meningkatkan hasil belajar peserta didik pada tema 4 subtema 2 pembelajaran 6 dengan dengan media powerpoint. Penelitian yang dilakukan adalah Penelitian Tindakan Kelas (PTK) sebanyak tiga siklus, dengan setiap siklusnya terdiri dari dua pertemuan. Tahapan setiap siklusnya adalah perencanaan, pelaksanaan, observasi dan refleksi. Pada pra siklus peserta didik yang tuntas sebesar 35\%. Pada siklus I peserta didik yang tuntas setelah melaksanakan post test sebesar $60 \%$. Pada siklus II peserta didik yang tuntas setelah melaksanakan post test sebesar $90 \%$. Hasil ini menunjukan bahwa media powerpoint dapat meningkatkan hasil belajar peserta didik khususnya tema 4 subtema 2 pembelajaran 6 Kelas III di SDN 1 Karanganyar.
\end{abstract}

Kata kunci: Hasil belajar, project based learning, IPA

Social, Humanities, and Education Studies (SHEs): Conference Series https://jurnal.uns.ac.id/shes 


\section{PENDAHULUAN}

Pada kondisi pandemic, segala aktivitas utama hanya boleh dilakukan di rumah. Situasi seperti ini merupakan realitas baru yang juga dialami dunia pendidikan terutama pada pelajar. Karena keadaan seperti ini sehingga guru, orangtua, dan murid harus siap menjalani kehidupan baru (new normal) lewat pendekatan belajar menggunakan teknologi informasi dan media elektronik agar proses pengajaran dapat berlangsung dengan baik. Pada konteks yang lain, semua pihak diharapkan tetap bisa optimal menjalankan peran barunya dalam proses belajar-mengajar di masa pandemi ini.

Pendidik yang cerdas harus pandai dalam memilih media pembelajaran yang sesuai dengan materi. Saat ini kebanyakan peserta didik menyukai kemajuan teknologi interaktif (bersifat saling melakukan aksi) dalam artian ada banyak gerakan animasi pada display (tampilan). Oleh karena itu, pendidik yang tugasnya sebagai fasilitator, pendidik harus bisa memahami keinginan peserta didik yang sesuai dengan zamannya.

Untuk menyikapi pembelajaran model jarak jauh/daring, guru harus menguasai media yang memungkinkan kegiatan pembelajaran jarak jauh/daring. Tentunya media yang dipilih oleh guru sudah dikuasai juga oleh siswanya Untuk mengatasi hal tersebut guru akan menggunakan media power point untuk melaksanakan kegiatan pembelajaran online/daring yang memungkinkan guru berinteraksi lebih komunikatif.

Hasil observasi awal terhadap siswa kelas IIIA SD Negeri 1 Karanganyar sebelum menggunakan media powerpoint, hasil belajar siswa pada pembelajaran tematik materi kewajiban dan hakku masih rendah dari KKM di SD NEGERI 1 Karanganyar yaitu 70. Jika dilihat dari hasil saat observasi sebagian besar masih di bawah kriteria ketuntasan minimal (KKM) yaitu sebesar $83,34 \%$, hanya $35 \%$ siswa yang telah memenuhi standar ketuntasan minimal .Dengan rata -rata kelas sebesar 64,5. Perlunya inovasi dalam pembelajaran ini tentunya diharapkan dapat meningatkan kualitas pembelajaran siswa khususnya di masa adaptasi kebiasaan baru (New Normal) pada siswa kelas IIIA Semester 1 Tahun Pelajaran 2020/2021 di SDN 1 Karanganyar Kecamatan Karanganyar Kabupaten Purbalingga, Jawa Tengah. Dan, aktivitas siswa kelas III pada saat pembelajaran berlangsung, yaitu siswa kurang berperan aktif, sebagian siswa hanya mendengarkan, siswa tidak tertarik dengan kegiatan pembelajaran, sehingga kurang adanya interaksi yang komunikatif selama proses pembelajaran. Pembelajaran masih di dominasi oleh guru, dan guru belum menggunakan media pembelajaran yang dapat menarik minat siswa.

Berdasarkan latar belakang yang telah diuraikan di atas, dengan mempertimbangkan solusi, peneliti menganggap bahwa penggunaan media powerpoint sangatlah penting, sehingga perlu dilakukan penerapan media tersebut ke dalam pembelajaran melalui penelitian yang berjudul "Penggunaan Media Powerpoint untuk Meningkatkan Hasil Pembelajaran Tema 4 Subtema 2 Pembelajaran 6 Pada Siswa Kelas III SD Negeri 1 Karanganyar Tahun Pelajaran 2020/2021"

\section{METODE}

Penelitian ini adalah penelitian tindakan kelas (Classroom Action Research) Penelitian tindakan kelas ini terdiri dari empat tahapan dasar yaitu perencanaan (planning), pelaksanaan (acting), pengamatan (observing) dan refleksi (reflecting). Analisis penelitian ini adalah analisis deskriptif kuantitafif kualitatif dimana dalam penelitian ini selain penyajian hasil berupa data maupun angka peneliti juga menentukan bagaimana cara pengolahan hasil penelitian yakni dengan membuat analisisnya. Penelitian ini dilaksanakan pada peserta didik kelas III SD Negeri 1 Karanganyar Tahun Pelajaran 2020/2021 selama dua siklus secara daring menggunakan media powerpoint dengan dua pertemuan disetiap siklusnya. Siklus I dilaksanakan pada tanggal 16 November 2020. Siklus II dilaksanakan pada tanggal 23 November 2020. Teknik pengumpulan data yang dilakukan dengan observasi dan tes,

\section{HASIL DAN PEMBAHASAN}


SHEs: Conference Series 3 (3) (2020) 1016- 1019

Pada setiap pertemuan diadakan tes. Untuk mengetahui perkembangan peserta didik selama pembelajaran. Penelitian dilakukan secara berurutan mulai dari menentukan pertanyaan mendasar, merancang penelitian, menyusun jadwal, memantau proses, pengukuran minat siswa dan penilaian hasil. Pada pra siklus, peneliti mendapat hasil test dari nilai terakhir sebelum diberlakukan Tindakan penelitian. Berikut ini adalah hasil belajar peserta didik pada pra siklus yang bisa dilihat pada tabel beriku

Tabel 1. Hasil Belajar Peserta Didik Pra Siklus

\begin{tabular}{|c|c|c|c|c|}
\hline \multirow{3}{*}{ Pra Siklus } & \multicolumn{4}{|c|}{ Test } \\
\hline & \multicolumn{2}{|c|}{ Pesdik tuntas } & \multicolumn{2}{|c|}{ Pesdik belum tuntas } \\
\hline & Jml & $\%$ & $\mathrm{Jml}$ & $\%$ \\
\hline Hasil & 7 & 35 & 13 & 65 \\
\hline
\end{tabular}

Berdasarkan tabel di atas maka terjadi peningkatan antara test pada pertemuan 1 . Setiap individu peserta didik sudah mengalami peningkatan hasil belajarnya. Peserta didik mengalami peningkatan hasil belajar pada pertemuan 1. Ketuntasan klasikal juga mengalami peningkatan, pada pertemuan 1 hanya 7 peserta didik yang tuntas tetapi pada pertemuan 2 bertambah menjadi 11 anak yang sudah tuntas dengan Kriteria Ketuntasan Minimal (KKM) sebesar 70. Demikian juga pada pada peserta didik yang belum tuntas, awalnya terdapat 13 anak yang belum tuntas dan di pertemuan 2 tingkat peserta didik yang belum tuntas menurun menjadi 9 siswa. Persentase ketuntasan klasikalnya meningkat, jika pertemuan 1 hanya $35 \%$ maka pada pertemuan 2 menjadi $45 \%$.

Berdasarkan refleksi pada pra siklus maka diputuskan diadakan penelitan menggunakan media pembelajaran yang lebih menarik dikarenakan belum mencapai ketuntasan klasikal yang diharapkan. Lalu, dilaksanakan penelitian siklus I. Siklus I membahas materi tentang hak berbicara, berkreasi dengan bilangan cacah melalui operasi pengurangan,Berikut ini adalah hasil belajar peserta didik pada siklus I yang bisa dilihat pada tabel berikut.

Tabel 2. Hasil Belajar Peserta Didik Siklus I

\begin{tabular}{|c|c|c|c|c|}
\hline \multirow{3}{*}{ Siklus I } & \multicolumn{4}{|c|}{ Test } \\
\hline & \multicolumn{2}{|c|}{ Pesdik tuntas } & \multicolumn{2}{|c|}{ Pesdik belum tuntas } \\
\hline & Jml & $\%$ & Jml & $\%$ \\
\hline Hasil & 12 & 60 & 8 & 40 \\
\hline
\end{tabular}

Berdasarkan tabel di atas maka terjadi peningkatan antara pra siklus dan siklus 1 . Setiap individu peserta didik sudah mengalami peningkatan hasil belajarnya. Ketuntasan klasikal juga mengalami peningkatan, terdapat 12 peserta didik yang sudah tuntas, dan terdapat 8 peserta didik yang belum tuntas dengan Kriteria Ketuntasan Minimal (KKM) sebesar 70. Persentase ketuntasan klasikalnya meningkat, jika pada pra siklus hanya $35 \%$ maka pada siklus 1 menjadi $65 \%$.

Dari hasil tersebut, karena pada pra siklus belum mencapai ketercapaian kriteria ketuntasan minimal yaitu $83,34 \%$ sehingga diadakan penelitian siklus II dengan materi pembelajaran yang sama namun persentasi pada medianya dibuat lebih menarik. Berikut adalah hasil dari siklus II. 
SHEs: Conference Series 3 (3) (2020) 1016- 1019

Tabel 2. Hasil Belajar Peserta Didik Siklus II

\begin{tabular}{ccccc}
\hline \multirow{2}{*}{ Siklus II } & \multicolumn{4}{c}{ Test } \\
\cline { 2 - 5 } & \multicolumn{3}{c}{ Pesdik tuntas } & Pesdik belum tuntas \\
\cline { 2 - 5 } & Jml & $\%$ & $\mathrm{Jml}$ & $\%$ \\
\hline Hasil & 16 & 80 & 4 & 20 \\
\hline
\end{tabular}

Berdasarkan table di atas maka terjadi peningkatan antara pra siklus, siklus 1 dan siklus 2. Terlihat hasil pada siklus II yait peserta didik yang tuntas berjumlah 16 siswa dan peserta didik yang belum tuntas berjumlah 4 siswa. Persentase ketuntasan juga meningkat menjadi $80 \%$.

Dari tiga siklus yang sudah dilaksanakan dipastikan bahwa model pembelajaran menggunakan media powerpoint dapat meningkatkan hasil belajar peserta didik pada Tema 4 Subtema 2 Pembelajaran 6 Kelas III di SD Negeri 1 Karanganyar. media power point ini merupakan media yang sangat tepat digunakan dalam proses belajar mengajar untuk membangkitkan dan meningkatkan motivasi belajar peserta didik. Pembelajaran merupakan interaksi antarpeserta didik, peserta didik dengan guru, dan peserta didik dengan sumber belajar pada suatu lingkungan belajar (Kemdikbud, 2014). Peserta didik dapat memahami materi tema 4 subtema 2 pembelajaran 6.

\section{SIMPULAN}

Penerapan media powerpoint dapat meningkatkan hasil belajar peserta didik Kelas III pada tema 4 subtema 2 pembelajaran 6 . Peningkatan yang terjadi karena adanya kesan pembelajaran yang mendalam dari peserta didik tehadap materi yang diajarkan melalui setiap slide yang dibuat. Peserta didik akan selalu teringat akan materi yang diajarkan dikarenakan mereka menemukan dan membangun sendiri pengetahuan mereka pada saat pembelajaran. Berdasarkan penelitian yang telah dilaksanakan salah satu media pembelajaran yang harus dikuasai guru adalah media powerpoint karena model ini sangat cocok digunakan dalam keadaan pandemi seperti ini, apalagi dalam kondisi belajar dari rumah. Peserta didik akan membangun pengetahuannya sendiri dengan proyek yang sudah disepakati. Guru bisa memantau proses selama proyek dilaksanakan dengan bekerja sama denagn orang tua.

\section{DAFTAR PUSTAKA}

Azhar Arsyad, Media pembelajaran, (Jakarta: PT. Raja Grafindo Persada, 2007) Asnawir dan Basyiruddin Umar, Media Pembelajaran, cet. I; (Jakarta; Ciputat Perss, 2002) Iriawan, Sandi. 2019. Modul 6 Pembelajaran di SD Berbasis TIK KB 2 Media Pembelajaran Tematik Berbasis TIK. Jakarta: Kementrian Pendidikan dan Kebudayaan

Kim, C., Mirusmonov, M., Lee, I. (2010). An Empirical Examination of Factors Influencing the Intention to Use Mobile Payment. Computers in Human Behavior, 26 (1), 310-322.

Johnson, B. \& Christensen, Larry. (2012). Educational Research: Quantitative, Qualitative, and Mixed Approaches (4th ed). London: SAGE Publication Ltd.

Hakim, C.. (2016, Juni 16). Kode Morse THR. Kompas Online. Diakses dari http://www.kompas.com

Young, R.F. (2007). Crossing Boundaries in Urban Ecology (Doctoral Dissertation). Tersedia dari Proquest Dissertation \& Theses Database.

Kementrian Pendidikan dan Kebudayaan RI. (2011). Peraturan Mendiknas tentang Satuan Pengawasan Internal (Permendiknas Nomor 47 tahun 2011). Jakarta: Penulis. 
